\title{
Mitigating humanitarian crises during non-international armed conflicts-the role of human rights and ceasefire agreements
}

\author{
Lottie Lane
}

\begin{abstract}
Background: Situations of humanitarian crisis are often caused by armed conflicts. Given the prevalence of non-international armed conflicts today, ways of ameliorating these situations are at the forefront of concerns. The international humanitarian law rules governing non-international armed conflict remain much less developed than those for international armed conflicts. This makes governing the behaviour of non-state parties to non-international armed conflicts (non-state armed groups) extremely challenging. This is exacerbated by the lack of direct human rights obligations for non-state armed groups. Although several initiatives have been taken to encourage non-state actors to mitigate situations of humanitarian crisis, the role of human rights law is somewhat under-developed in this respect.
\end{abstract}

Method: The paper aims to assess what role human rights may have in improving humanitarian crises, suggesting one specific way in which they may be used. In order to achieve this, the paper will first discuss the international laws applicable to situations of non-international armed conflict. The paper will then critically analyse some of the initiatives that have already been taken to mitigate the disparity in human rights protection during armed conflicts.

Results: Based on the findings of this analysis, a new measure- - the possibility of using a ceasefire agreement to impose specific human rights obligations on all parties to a conflict—will be assessed.

Conclusions: An evaluation of the merits and challenges raised by this suggestion will lead to a conclusion as to the role that human rights and ceasefire agreements could have during humanitarian crises.

Keywords: Humanitarian crisis, Economic, social and cultural rights, Non-state armed groups, Ceasefire agreements

\section{Background}

The non-international armed conflict in Syria has been proclaimed as causing the "biggest humanitarian emergency in our era" (Peralta 2014). The combination of a repressive regime, armed opposition groups and terrorist activities has left the country in a constant state of instability and chaos. Millions of people have been forced to live in abject conditions, without access to basic living supplies such as food, water and shelter. The ongoing grapple for power between the Islamic State and the Syrian government exacerbates the already dire situation. This paper will assess the potential role of ceasefire agreements in imposing human rights obligations for non-state armed groups (NSAGs) in efforts to ameliorate situations of humanitarian crisis caused by non-international armed conflicts. The ultimate aim of the

Correspondence: c.l.lane@rug.nl

University of Groningen, Oude Kijk in 't Jastraat 26, 9712 EK, Groningen, The Netherlands

\section{Springer}

paper is to build upon existing literature to suggest a way in which the inapplicability of human rights law to non-state armed groups could be circumvented during situations of humanitarian crisis in non-international armed conflicts (NIAC). The research question posed in this paper differs somewhat from the existing literature concerning the application of human rights law to NSAGs as it ties this discussion to the issue of humanitarian assistance.

\section{Method}

The paper will first discuss the international law applicable to situations of non-international armed conflict. This will involve a brief explanation of the doctrine of lex specialis, necessary for identifying the applicable law during non-international armed conflicts, and the standards to which parties to the conflict may be held. The analysis will then focus on economic, social and cultural rights, as the most relevant for improving access to food, water and shelter. The section aims to demonstrate the 
aggravation of situations of humanitarian crises caused by the lack of direct human rights obligations for armed opposition groups. The next section of the paper will critically analyse some of the initiatives that have already been taken to improve inadequate human rights protection during armed conflicts, made worse by the differences in human rights obligations between non-state and state parties to a conflict. Based on the findings of this analysis, a new measure-the possibility of using a ceasefire agreement to impose specific human rights obligations on all parties to a conflict-will then be assessed. This will include an evaluation of the merits and challenges raised by this suggestion, leading to a conclusion as to the role that human rights and ceasefire agreements could have during humanitarian crises.

\section{Results}

Applicable rules of international law

The laws applicable to armed conflicts are extremely well rehearsed (Solis 2010; Clapham and Gaeta 2014) and will be only briefly laid out below. The following section will focus on non-international armed conflicts taking place between a state and (one or more) nonstate armed group. For the purposes of the paper, the term 'non-state armed group' shall refer to a definition of a non-state actor as suggested by Geneva Call. It shall therefore include "any armed group, distinct from and not operating under the control of, the state or states in which it carries out military operations, and which has political, religious, and/or military objectives" (Bellal et al. 2011, 48). ${ }^{1}$

\section{Applicability of international humanitarian law}

The corpus of international humanitarian law applicable during NIAC is somewhat limited compared to that relating to international armed conflicts. In the early days of international law, the lack of development was perhaps due to a general understanding that because of its domestic nature, internal warfare fell within the scope of states' national jurisdiction and need not be regulated internationally (Moir 2002, 2). Although some customary international law pertaining to NIAC existed (relating particularly to the recognition of belligerency), state practice on the matter rapidly declined (Moir 1998, 352). However, as the prevalence of internal conflicts grew, and the transnational effects of NIAC became more evident (e.g. the influx of refugees and/or a 'spill-over' of hostilities to neighbouring states: Moir 2002, 2) and the realisation that parties most affected by conflicts (i.e. civilians) were in need of protection regardless of the nature of the conflict, the mid-twentieth century brought a greater acceptance of the application of humanitarian norms to NIAC. Nonetheless, despite efforts of the International Committee of the Red Cross to encourage the application in practice (having adopted a resolution on the matter in 1938: Moir
$1998,354)$, progress was stopped short by the breakout of World War II. It was therefore not until 1949, after a rejection of the International Committee of the Red Cross (ICRC)'s attempts to have the totality of international humanitarian law extended to cover NIAC, that the somewhat restrictive Common Article 3 to the universally binding Geneva Conventions (Best 1994, 82-83; ICRC 1949a; ICRC 1949b; ICRC 1948c; ICRC 1949d) was adopted. ${ }^{2}$ The NIAC-specific Additional Protocol II to the Geneva Conventions of 12 August 1949 (ICRC 1977) was later hastily adopted in 1977, after further disagreements between states as to the extent to which their internal affairs should be opened to external scrutiny (see Best, 346-347).

The standards contained in these instruments apply to both state and non-state parties to a NIAC. This assertion has raised several conceptual concerns, perhaps the most notable relating to the legitimacy of applying treaty standards to NSAGs, who have not ratified the relevant treaties. At the international level, in the absence of an elected world government, the legitimacy of obligations stems from the sovereign equality of states and the fact that they bind only themselves through the creation and adoption of international norms. The source of legitimacy for the imposition of direct obligations on non-state actors at the international level without their participation therefore raises some questions. Justifications proffered range from the 'doctrine of state jurisdiction' ${ }^{3}$ to the analogy of individual criminal responsibility. ${ }^{4}$ Perhaps the most persuasive justification is the argument that some procedural requirements of legitimacy need not be followed in relation to norms preventing heinous conduct. It has been argued, for example, that if the expected result of the obligations' implementation is of paramount importance, it may negate the necessity of the norms being adopted with the consent of affected parties (Ryngaert 2010, 71-73). Ryngaert asserts that in the absence of participation by a non-state actor, if a "legal norm or its implementation has in itself an important substantive value", participation is not necessary (Ryngaert 2010, 71). Arguably, in the case of international humanitarian law that was extended to NIAC primarily for the purpose of protecting civilians, this argument rings true. Indeed, "it has now become uncontroversial...that [NSAGs] are bound by international humanitarian law" (Bellal et al. 2011, 56).

However, a high threshold must be met for Additional Protocol II to be applicable. ${ }^{5}$ This means that in many situations, only Common Article 3 providing minimal protections would apply, as the provision automatically applies upon the classification of a situation as a noninternational armed conflict. By now, however, this body of law has matured, with a more expansive corpus of customary international humanitarian law applying to NIAC (Sivakumaran 2012, 102). Notwithstanding criticism of this customary law, its application to NSAGs has 
been more broadly accepted than the application of treaty-based rules (Bellal et al. 2011, 56).

In addition, the assertion that some rules of international armed conflicts are also applicable in NIACs is becoming more commonplace (Columbia Law School Human Rights Institute, cited in Cleveland 2014). These evolutions in the law of NIACs have taken place predominantly to counter concerns that despite the widespread nature of NIACs, the laws applicable during an international armed conflict were much more extensive in scope. Until the 1990s, developing the rules of NIAC beyond those provided for by Geneva law was "never seriously entertained" (Sivakumaran 2012, 55). With the majority of armed conflicts currently occurring worldwide being non-international in nature (Armed Conflict 2014), ${ }^{6}$ the developments are now a welcome opportunity to mitigate the human suffering caused by armed conflicts and thwart concerns regarding the deregulation of NIACs. ${ }^{7}$

Now that the law applicable during NIAC is in a more (though by no means fully) developed state, the primary issue to be addressed is how to ensure that NSAGs comply with the relevant norms and close the gap between law and practice during NIAC. Aligning the practice of NSAGs with the legal standards is an extremely challenging task, however. On the one hand, NSAGs may not be aware of the existence or meaning of humanitarian norms and may lack the institutional structure to ensure compliance of their own fighters (Ryngaert and Van de Meulebroucke 2012, 456-457). Alternatively, a NSAG may be unwilling to engage with the notion that it has legal obligations under humanitarian law (e.g. ICRC 2008). Even those NSAGs willing to abide by the laws may encounter an array of obstacles in implementing them. ${ }^{8}$ It is for this reason that organisations such as the International Committee of the Red Cross have engaged with NSAGs that have expressed a desire for help. Nonetheless, as Ryngaert and Van de Meulebroucke note, unlike for states, there is no formal advisory service available to NSAGs struggling to comply (Ryngaert and Van de Meulebroucke 2012, 457).

Notwithstanding the difficulties faced in ensuring NSAGs' compliance with humanitarian law, there is growing support for the application of international human rights law to situations of armed conflict, which will be explained in the following section.

\section{Applicability of international human rights law}

The rhetoric pertaining to the application of international human rights law to armed conflicts was initially somewhat divergent. A major focus of this debate has revolved around the doctrine of lex specialis derogat legi generali (lex specialis), which many believed to render the application of human rights during armed conflicts inappropriate (e.g. Schabas 2007, 594). As the literature engaging with this debate is extremely extensive, this section will present a summary of the doctrine and its consequences within the context of this paper. The doctrine mandates that more precise and specialised law is to take precedence over more general laws. Reluctance to apply human rights law during armed conflicts was also due to the differing natures and 'roots' of humanitarian and human rights law (Solis 2010, 24). On the one hand, humanitarian law (not seeking to abolish conflict) does not prohibit the immediate killing of the enemy. It seeks rather to diminish the devastating human cost of conflicts and to ensure a fairer fight (ICRC 2004). ${ }^{9}$ Human rights law, on the other hand, seeks to protect individuals from potentially abusive actions by states and does not allow the arbitrary taking of life under any circumstances. ${ }^{10}$

Furthermore, as is explained below, human rights law imposes obligations on the state for the benefit of individuals. The relationship between the obligation-holder and the beneficiaries (or rights-holder) is thus inherently vertical in nature. In contrast, as explained above, many humanitarian obligations are owed by all parties to the conflict, which act essentially as mutual beneficiaries (assuming that all parties comply with their obligations).

In more recent years, the international community has increasingly accepted the view of the International Court of Justice (ICJ) in its Advisory Opinion on the Legality of the Construction of a Wall in the Occupied Territory that during armed conflicts international humanitarian norms and international human rights norms may apply simultaneously, in a complementary manner (Legal Consequences of the Construction of a Wall in the Occupied Palestinian Territory, Advisory Opinion 2004, para 106). It may be said, therefore, that the doctrine of lex specialis serves more to determine the precise rules to apply to a particular situation, rather than precluding application of one body of law. This view is supported by Marko Milanović, who has highlighted that understanding the doctrine as being generally applicable to the human rights and humanitarian regimes as a whole, is mistaken (Milanović 2011, 98-101). Following Kreiger, Milanovićs suggestion is to assess which rule constitutes the lex specialis by looking at the relationship between specific norms, rather than regimes as a whole (Milanović 2011, citing Kreiger 2006). The present paper will also depart from this starting point, understanding the lex specialis during situations of humanitarian crisis as being human rights law.

\section{Economic, social and cultural rights}

Having established that international human rights law as such may be applicable during non-international armed conflicts, the following section will address the application of economic, social and cultural rights. The rights usually forming the subject of debates concerning 
the lex specialis during armed conflicts are civil and political rights, such as the right to life and the prohibition of torture. This is perhaps due to the existence of concrete norms in humanitarian law which also provide rules on the use of torture and the taking of life, ${ }^{11}$ although they differ from human rights law. However, the rights affected (and applicable) during armed conflicts are not limited to those whose subject matter is also dealt with by norms under humanitarian law. When concerned with humanitarian crises that result in heavily reduced access to materials and services essential to a life of dignity, often referred to as 'subsistence rights' (such as healthcare, food, and water and sanitation), economic, social and cultural rights are of the utmost relevance.

It may well be argued that in relation to the provision of food and water during armed conflicts, human rights law constitutes the lex specialis. As implied above, deciphering which norm/s form the lex specialis in a given circumstance will require an examination of which norms are the most developed. In the present context of subsistence rights, human rights law has not only been given more content than the relevant humanitarian law norms but also provides (in theory) more extensive protection of access to essential materials and services.

For example, humanitarian law rules do prohibit the use of starvation as a method of warfare and the targeting of essential resources (being classed as civilian objects), ${ }^{12}$ thereby providing limited protection of materials. The rules on access to humanitarian aid are more developed for international armed conflicts. For non-international armed conflicts, however, the applicable treaty rules do not explicitly refer to humanitarian aid (Swiss Federal Department of Foreign Affairs 2011, 25-26). Regardless, the Swiss Federal Department of Foreign Affairs has interpreted Common Article 3 to include a principle that civilian populations may not be intentionally subjected to situations that would, due to a lack of access to essential supplies, threaten their dignity or result in "serious mental or physical suffering" (Swiss Federal Department of Foreign Affairs 2011, 26). However, these rules are constructed as 'negative' obligations-prohibitions of certain conduct requiring parties to refrain from interfering with access to essential supplies. Whilst the same obligations can be found under economic, social and cultural rights, human rights law goes further, requiring states parties to not only respect the rights (i.e. refrain from interfering with their enjoyment) but also protect and fulfil the rights by providing the means and/or substance for the right to be effectively realised (Shue 1980, 260; Eide 1987). ${ }^{13}$

In addition, the rule in Common Article 3 relating to the lack of access to essential supplies is not buttressed by a wider range of provisions applicable during NIAC. Indeed, humanitarian assistance (i.e. the provision of food, water and healthcare) as such is scarcely regulated during NIAC, which may raise a presumption that human rights law constitutes the lex specialis. Provisions regulating humanitarian assistance during international armed conflicts can be found in (for example) Article 23 Geneva Convention IV and Article 70 Additional Protocol I (see ICRC, 2014). However, other provisions relating to humanitarian assistance during NIAC are limited to Article 18 Additional Protocol II. This article provides for the undertaking of humanitarian "relief actions" (with the consent of the concerned state party) in the event that the "civilian population is suffering undue hardship owing to a lack of the supplies essential for its survival" (Article 18, para 2). The very vagueness of this protection, extending to "foodstuffs and medical supplies" suggests that the much more embellished human rights law would offer more protection of subsistence rights than humanitarian law. It may be argued that the Manual on the Law of NonInternational Armed Conflict 2006 (the San Remo Manual) provides further detail in this respect. The manual is a restatement of the law applicable during NIAC, though like the ICRC codifications of law, it is not legally binding. Chapter 5 of the Manual states that "humanitarian assistance should be allowed and facilitated by those engaged in military operations whenever essential needs in an emergency are not being met" and provides more information on the definition of humanitarian assistance. The Manual still refrains from placing positive obligations on parties to the conflict to ensure that the essential needs are, in fact, met. Taken together with the lack of more detailed information on what constitutes essential foodstuffs etc., this contributed to the argument that the lex specialis in the present context is human rights law.

Further support for the argument that human rights law constitutes the lex specialis in relation to a humanitarian crisis caused by a NIAC may be found in the nonlimitation and non-derogability of subsistence rights in such a situation. The implications of these two aspects of subsistence rights and the nature of the obligations deriving from them, as economic, social and cultural rights, will now be explained.

\section{Limited application of economic, social and cultural rights}

A. Legitimate limitations of human rights

Despite the general applicability of economic, social and cultural rights in times of armed conflict, there are measures which states may take to restrict the scope of their obligations. These consist primarily of derogations and limitations of the rights. However, as Müller (2009) has suggested, the legitimacy of invoking these methods during an armed conflict is, at least regarding the abovementioned subsistence rights, questionable. ${ }^{14}$ 
Legitimate limitations to economic, social and cultural rights are allowed under Article 4 of the International Covenant on Economic Social and Cultural Rights (ICESCR) for the promotion of the general welfare in a democratic society, providing that they are not contrary to the nature of the right. This sole reason justifying limitations is more restrictive than the several reasons found in the International Covenant on Civil and Political Rights 1966a (ICCPR). Article 19 ICCPR on freedom of expression, for example, allows limitations for several reasons, including the respect of the rights or reputation of others, the promotion of national security or pubic order, or of public health or morals. Müller has persuasively argued that this reason effectively means that states may not limit the 'minimum core' of economic, social and cultural rights, since they would go against the nature of the rights (Müller 2009, 575). ${ }^{15}$ In addition to these requirements, limitations to economic, social and cultural rights must be prescribed by law, proportionate to the aim pursued, and necessary in a democratic society. Furthermore, as the Limburg Principles on the Implementation of the International Covenant on Economic, Social and Cultural Rights state, "[article 4] was not meant to introduce limitations on rights affecting the subsistence...of the person." (United Nations Commission on Human Rights 1987, para 47). Taken together with the nature of subsistence rights as providing for the basic necessities required for human existence, it can therefore be inferred that limitations to subsistence rights would not be considered legitimate.

B. Derogations from economic, social and cultural rights The question of whether state parties may derogate from economic, social and cultural rights in times of public emergency has been a matter of much debate. Derogating from a right essentially allows states to put their obligations on hold for a specified period of time. As derogating is a somewhat extreme measure, whether or not a particular right may be derogated from, and under which circumstances, is usually laid down in the text of a human rights treaty. However, this is not the case for the ICESCR, which neither contains a derogation clause allowing for derogations, nor a provision prohibiting derogations. This is unlike the ICCPR, Article 4 of which specifies the conditions for derogations from its provisions, and prohibits derogations from several rights (Article 4, paragraphs 1 and 2, respectively). Nonetheless, the fact that there is no derogation clause in ICESCR does not necessarily mean that states would be precluded from derogating from them.
However, it can be inferred from the purpose of derogation clauses that at least some economic, social and cultural rights are non-derogable. According to Müller, this would extend to subsistence rights (Müller 2009, 593). The purpose of derogations is not to allow states to decrease their attention to the rights, but (following the criteria of Article 4 ICCPR) must be to ensure that the state is in a position where it is capable of ensuring human rights and to restore a situation of normalcy (United Nations Human Rights Committee 2001, para 1). This is evident from the requirement that a state be in a "time of public emergency that threatens the life of the nation" before it may make derogations. Whilst it may be true that a non-international armed conflict may cause such a situation of public emergency, it cannot reasonably be expected that derogating from rights such as the right to food, water and healthcare, could help to restore the state to a situation of normalcy. On the contrary, reducing access to essential resources would aggravate, rather than ameliorate, a situation of public emergency. Allan Rosas and Monika Sandvik-Nylund have also suggested that the relationship between subsistence rights and the right to life can contribute to the argument in favour of the non-derogability of subsistence rights (Rosas and Sandvik-Nylund, 2001, 414). Subsistence rights are of the utmost importance for the protection of human dignity and survival in emergency situations and are interrelated with the right to life-a non-derogable right (to the extent that a life may not be arbitrarily taken) (see Müller 2009, 599). This view is supported by several human rights bodies which, lacking jurisdiction over (or the justiciability of) economic, social and cultural rights, have interpreted the right to life to include subsistence rights. For example, the Inter-American Court of Human Rights has repeatedly read the right to life (protected by Article 4 of the American Convention on Human Rights) to include healthcare as one of its essential attributes (see Case of Children's Rehabilitation v. Paraguay 1999). This reading is now "solidly part" of the Court's jurisprudence, having been embellished upon in several cases (e.g. Yakye Axa Indigenous Community v. Paraguay 2006, discussed in Melish 2008, 389).

C. The nature of ESCR

Whether or not the manner of using the right to life in this way is found to be persuasive for present purposes, the fact that Article 2(1) ICESCR allows economic, social and cultural rights to be progressively realised is also of relevance here. ${ }^{16}$ The provision means that whilst some immediate measures have to be taken by states to contribute to 
the realisation of economic, social and cultural rights, their full realisation is not an immediate obligation.

States must, however, make continuous and progressive measures to increase the realisation of the rights, depending on their available resources. Whilst it may be argued that a state has less resources available during armed conflicts, which would naturally lead to a lesser degree of the rights' realisation, the Committee on Economic, Social and Cultural Rights (CESCR) has introduced a concept of 'minimum core obligations' of the Covenant rights (CESCR 1990, para 10). Simply speaking, this means that there is a certain floor of human rights realisation that states must ensure, regardless of their particular domestic situation. In relation to the rights to food, water, and highest attainable standard of health, which have been given more content through CESCR's General Comments 12,15 and 14, respectively, the minimum core would arguably provide more protection of subsistence rights than the norms under humanitarian law, despite their progressive nature.

In addition, the Committee has suggested that the notion of progressive realisation makes it extremely cumbersome for states to justify any retrogressive measures. ${ }^{17}$ The extent to which this would also hold true during armed conflicts, during which time resources may need to be redistributed, is unclear. However, it may be deduced that at least the minimum core of subsistence rights may not be derogated from, even during situations of public emergency threatening the life of the nation. This conclusion is particularly significant when viewed in light of the below discussion on the absence of human rights obligations for NSAGs. If subsistence rights were derogable, it would mean that the obligations on the state and NSAGs would be more equal and would provide some level of justification for the fact that individuals' rights were not being realised.

The above discussion demonstrates that the more embellished standards relating to the provision of food, water and healthcare found within international human rights law makes these norms, rather than those found in humanitarian law, the lex specialis in the present context. This finding is strengthened by the conclusion that subsistence rights are non-derogable and may not be limited during NIAC. Unfortunately, whilst this affords perhaps more protection to individuals within territory controlled by a state, it leaves individuals in areas controlled by NSAGs (as non-human rights obligations-holders) without human rights protection. This problem and efforts to use human rights law to remedy the gap in protection through the indirect application of human rights obligations to NSAGs will now be assessed.
NSAGs and the indirect horizontal effect of human rights Under the current international human rights framework, NSAGs do not have direct human rights obligations; as non-state actors, NSAGs cannot be party to international human rights treaties. Rather, human rights obligations are vertical in nature, being owed by the state on a vertically superior legal plane, to individuals. Unlike other international treaties, human rights treaties do not even have horizontal application, or 'horizontal effect' between states. Human rights treaties allow for neither substantive horizontal effect (i.e. allowing individuals to claim violations of actual rights owed to them by NSA), nor procedural horizontal effect, often known as drittwirkung ${ }^{18}$ (reflected in the rule that complaints of human rights violations may only be brought before the human rights treaty bodies by individuals against states) (e.g. Optional Protocol to the International Covenant on Civil and Political Rights 1966c, Article 1).

However, the ever-increasing power and influence of non-state actors (including NSAGs) and their ability to interfere with the enjoyment of human rights has led to an application of 'indirect horizontal effect' by many human rights monitoring bodies and courts. Although being achieved through several different methods, indirect horizontal effect essentially holds states responsible for human rights interference resulting from the conduct of nonstate actors. In the past, this has been used in relation to corporations, NSAGs, and even individuals (e.g. European Court of Human Rights (ECtHR) Fadeyeva v. Russia 2005; United Nations Committee against Torture Sadiq Shek Elmi v. Australia 1999; ECtHR, $X$ and $Y$ v. The Netherlands 1985). Perhaps the most prevalent way of achieving indirect horizontal effect is to use states' positive obligation to protect individuals from human rights interference with the enjoyment of their rights.

The obligation has been fleshed out using a 'duty of due diligence'. Under international human rights law, this means that states must take all appropriate measures to 'prevent, investigate and punish' third party interference with human rights enjoyment (Inter-American Court of Human Rights Velásquez-Rodríguez v. Honduras 1988, paras 79,172$)$. When assessing whether or not a state has acted with due diligence, the focus is on the conduct, and the progressive measures that states took in a particular situation, rather than the result of the measures and whether or not they were actually successful in protecting an individual (Office for the United Nations High Commissioner for Human Rights 2005, 61). In practice, this means that a state will not be expected to protect every individual all of the time. Rather, they will be expected to take protective measures when they know, or should have known, of a threat to an individual's rights by a third party (see, e.g. ECtHR, Osman v. United Kingdom 1998b; ECtHR, $Z$ and Others v. United Kingdom 2001, ECtHR Kaya v Turkey 1998a).

Whereas this is arguably more reasonable for states, it has obvious flaws in relation to non-state actors outside 
of state control, such as NSAGs. An illustrative example is that of the Fuerzas Armadas Revolucionarias de Colombia (FARC) in Colombia. The non-international armed conflict between the NSAG and the state has been taking place for over 50 years, with the FARC having gained in 2000 effective control over a large area of Colombian territory (Rollins 2010, 18). The Human Rights Council has expressed concern at the lack of inquiry and investigation into crimes committed by demobilised individuals from the FARC against women and children, in particular the recruitment of child soldiers (Human Rights Council, Working Group on the Universal Periodic Review 2008, para 57).

This would also presumably fail to comply with the state's obligation under Article 4(2) of the Optional Protocol to the Convention on the Rights of the Child on the Involvement of Children in Armed Conflict (2000) to "take all feasible measures" to ensure that the relevant norms are respected. The Inter-American Commission on Human Rights emphasised the importance of the obligation to investigate and punish actions by NSA in its assessment of whether Colombia had acted with due diligence in relation to FARC activity, but ultimately stated that "in situations of civil strife, the State cannot always prevent, much less be held responsible for, the harm to individuals and destruction of private property occasioned by the hostile acts of its armed opponents." (Inter-American Commission on Human Rights, Organization of American States 1999, Chapter IV para 4, discussed in Clapham 2006b, 422). This appears to place a lower (albeit more realistic) burden on states than the European Court of Human Rights. In the case of Illascu and others v. Moldova and Russia (1999), the Court was called upon to question the responsibility of Moldova for harm that occurred in an area of its territory over which it no longer had effective control. The Court opined that "States retain the obligation to use all means and resources available to them to guarantee human rights" (para 333) and upheld Moldova's responsibility. Whilst encouraging states to make efforts to guarantee human rights throughout its territory regardless of situations of conflict is laudable, finding the state to have violated its obligations in areas where it is no longer capable of securing human rights is questionable. Although the approach of the Inter-American Commission may appear to be too soft-handed, the much more heavy-handed approach of the ECtHR has been questioned, not least by dissenting judges (Illascu and Others v. Moldova and Russia 1999, Partly Dissenting Opinion Of Judge Sir Nicolas Bratza).

Ultimately, whichever view is taken could result in a gap in human rights protection. Even if a state were to use all means and resources available to try to secure human rights in areas controlled by NSAGs, it may not be possible. Additionally, and unfortunately, the vast majority of previous cases upholding indirect horizontal effect have been in relation to civil and political rights. Until recently, it was not possible to bring an individual complaint in relation to rights contained in the International Covenant on Economic, Social and Cultural Rights. ${ }^{19}$ The entry into force of the Optional Protocol to the Covenant now allows for this possibility, but it remains to be seen how the Committee on Economic, Social and Cultural Rights will deal with such situations. ${ }^{20}$ These factors all culminate in a gap in effective legal protection of subsistence rights during armed conflicts. Whilst some NSAGs take it upon themselves to provide public services and to essentially fulfil some human rights on a de facto basis, there exists a legal lacuna. A correlative of this is an inequality in human rights protection. Victims living in an area controlled by the state may still be able to receive redress for their human rights violations by bringing a complaint directly against the state. For those living in NSAG-controlled areas, depending on the situation on the ground and the efforts that states have made in securing human rights enjoyment despite the control of the NSAG, this may not be possible. Individuals suffering the effects of severe humanitarian crises may therefore be left with no way of accessing essential materials. Despite laudable efforts by humanitarian aid organisations to deliver materials to those in need, and the humanitarian norms prohibiting the restriction of their access to areas in need of essential materials, ${ }^{21}$ some areas remain rife with crisis. For these reasons, more measures need to be taken to try to achieve a rounder, more comprehensive protection of human rights.

This contrasts with international humanitarian law, which contains the fundamental principle of equality of obligations. ${ }^{22}$ This means that all parties to a conflict owe the same obligations and hold the same rights "irrespective of the 'justness' of the cause", even during NIAC (Sivakumaran 2012, 242-246). Consequently, civilians belonging to both sides of the conflict are in theory equally protected from the effects of the conflict. However, the developments in the range of laws applicable during NIAC remains limited in comparison with international armed conflicts due to the reasons mentioned above. The limited scope of the norms renders the equality of obligations during NIAC less meaningful, particularly in situations where the high threshold for application of Additional Protocol II is not met. Indeed, the equality of obligations in NIAC was seemingly a response to the need to ensure equal protection for civilians during internal as well as international conflicts rather than to recognise NSAGs as bodies competent of discharging obligations.

In this respect, it is possible to compare the application of humanitarian law to NSAGs with that of human rights norms to some extent. States have shown a reluctance to impose direct obligations on non-state actors under both spheres of law, resulting in the (deliberate) 
gaps in the obligations of state vs. non-state actors. With respect to both legal fields, the primary reason for this is the prevailing state-centric, Westphalian approach to international relations. States are still considered to be the sole subjects of international law; sovereign entities endowed with the power and responsibility of managing their internal affairs (including the regulation of non-state actors). This is reflected, for example, in the fact that only states may be party to international human rights law treaties and the Geneva Conventions (including Additional Protocol II). Changes in the prevalence and power of NSAGs are highlighting the insufficiency of this paradigm for dealing with situations of humanitarian crisis during NIAC. Interestingly, some level of equality has been transposed into the younger field of international criminal law, which allows for individuals to be held individually criminally responsible for breaches of international humanitarian law. This is possible where an individual has committed one of the 'grave breaches' of the norms, some of which concern human rights principles. ${ }^{23}$ Nonetheless, the principles involved do not relate to subsistence rights. This makes the deterrent aspect of international criminal law less valuable in the context of humanitarian crises. Consequently, the gap in both humanitarian and human rights law makes it difficult to govern the actions of NSAGs effectively.

Christa Rottensteiner has noted, "the primary responsibility for meeting the needs of the civilian population in an armed conflict rests with the warring parties that are in effective control of the territory on which that population lives" (Rottensteiner 1999). As the international legal framework does not currently envisage NSAGs as obligation-holders, and in light of the lack of evidence of political will to alter this, extra-legal efforts are necessary to bring NSAGs' conduct in line with human rights standards and alleviate humanitarian crises caused by NIAC.

\section{Methods for improving the governance of NSAGs}

There have been numerous methods used to reduce the human cost of non-international armed conflicts, many of which also aim to more effectively govern the actions of NSAGs. The measures range from reports condemning the actions of the groups to voluntary undertakings by groups promising to adhere to particular international norms. The scope of the measures' contents is also variable, seemingly rendering specific examples more or less relevant to the issue of improving the fulfilment of subsistence rights during non-international armed conflicts. However, the common aims of each measure (being to engage with NSAGs and bring their conduct into compliance with particular legal standards) make each example discussed below relevant in the present context. Several previous initiatives will now be assessed to determine the likelihood of similar approaches being able to improve the protection of subsistence rights during situations of humanitarian crisis.

\section{Voluntary undertakings}

As can be seen on quite a widespread basis, NSAGs with effective control over an area of territory sometimes voluntarily undertake some human rights obligations. Whether the group itself views their actions in this way or not, there are many which have, on a de facto basis, begun to fulfil some human rights. These can range from the provision of some public services to the instatement of an internal justice system. This is often due to the group's ultimate goal of either taking complete control over a territory and becoming the new governmental authority or establishing a separate, smaller state within the territory of the state that they are in a conflict with. We can see examples of both of these instances if we look at the so-called Islamic State and the FARC, respectively. The mission of the Islamic State is to take control over a very large territory within the Levant, including Iraq and Syria (Australian National Security Database on Terrorist Organisations 2014). Within a relatively short period of time, the group gained effective control over an area of Syrian territory, establishing a 'capital' known as Raqqa (Hubbard 2014). Having obtained authority in this region, the Islamic State went on to establish what is essentially a state-like structure (Barnes-Dacey 2014). This has involved the group resecuring the provision of some public services, for example installing new power lines and setting up a 'suq' for locals to exchange goods, and reforming the education system (see Zelin 2014). Whilst the intentions of the group in doing these are most likely not related to human rights concerns, it could be argued that they are in effect providing some human rights to (at least some) individuals within Raqqa. However, obvious problems arise. There are concerns as to discrimination in the provision of the public services, and the inability of the Syrian state (or indeed of third states) to exercise control or influence over the group makes it virtually impossible for outside actors to improve the situation of humanitarian crisis within Raqqa.

The situation regarding the FARC is somewhat different. In 2000, the Colombian Government agreed to concede around $42,000 \mathrm{~km}^{2}$ to the non-state group. Some of the actions of the FARC within this area have been surprisingly state-like, as the group "deliver[s] social services, including healthcare and education. They also practise restorative justice through their revolutionary courts and have implemented agrarian reform by breaking up large ranches and turning over smaller plots to landless peasants. They also collect taxes from local businesses to fund schools and clinics" (Leech 2013).

This shows that the group has a very well-established and fully functioning community, and the fact that they 
are providing 'public' services such as education and healthcare suggests that they are capable of and actually are fulfilling these human rights within their controlled territory. ${ }^{24}$ The successful governance of at least this relatively large area by the FARC makes it not implausible that they would be able to orchestrate the required infrastructure to achieve this on a larger scale, were their armed forces be able to overtake a larger percentage of land from the state.

Voluntary undertakings in this manner are a promising development for subsistence rights. Many public services entail the provision of economic, social and cultural rights, such as healthcare. However, the nature of the undertakings makes them very hard to regulate and monitor. The lack of a concrete agreement or obligation means that the NSAG providing the services may choose the extent to which it wishes to provide a right. As with ISIS, this may in turn lead to discrimination in the fulfilment of rights. It is therefore desirable to have some form of agreement or statement by the NSAG specifying the scope of the rights and obligations they are willing to fulfil.

\section{Action plans and deeds of commitment}

There have been several initiatives taken by the United Nations and various non-governmental organisations to encourage NSAGs to adopt agreements specifying obligations with which they agree to comply. Most of the measures focus on humanitarian norms, rather than human rights law. This is logical, since NSAGs are subject to some humanitarian obligations, but the lack of pressure on groups to respect human rights norms distinctly from humanitarian norms could be a missed opportunity. Two of the largest initiatives taken to better govern the actions of NSAGs are the Security Council action plans and lists of shame (within the context of the recruitment and use of child soldiers) and Geneva Call's Deeds of Commitment. Lessons may be learned from these two examples as to the likely challenges to securing a human rights-specific undertaking by NSAGs. Indeed, experiences with the action plans and deeds of commitment can demonstrate whether a solution to the problem at hand (securing NSAGs' compliance with subsistence rights to alleviate humanitarian crises) may be found in these two measures.

\section{A. Action plans}

Action plans were introduced after the General Assembly's Special Representative had identified six "grave violations" towards children during armed conflict. The plans are formed following Security Council action in this context (see Office of the Special Representative of the Secretary-General for Children and Armed Conflict 2009, 2).
In 2001, the Security Council adopted a resolution which urged the Secretary-General of the United Nations to publish a list of all parties to armed conflicts who were recruiting or using child soldiers incompatibly with applicable obligations under international law, and in relation to situations which were, or could have been, on the agenda of the Security Council (see United Nations Security Council 2001, para 16). As a consequence, with the intention of "naming and shaming" armed forces, the first '1379 list' in 2002 contained 23 groups (Secretary General on Children and Armed Conflict 2002, cited in Harvey 2003, 29-30). A further resolution now obliges to provide reports to the Security Council on actions taken to ameliorate the situation (United Nations Security Council 2003, para 5, cited in Harvey 2003, 30).

A further initiative by the Security Council-the 'Action Plan' initiative-enables listed groups to have their names removed from the list of shame. The concept was developed in Security Council Resolution 1460 (2003) and involves an agreement between the listed group and the Security Council. If appropriately implemented, this will result in the removal of groups from the 'list of shame' (Office of the Special Representative of the Secretary General for Children and Armed Conflict 2015). This is a positive development because it allows the NSAG to have some level of negotiation with the United Nations, which may prove to be crucial to the ultimate goal of halting their use of child soldiers. Rather than affording the groups legitimacy, the lists make an example of the groups and place them on the 'naughty step'. In contrast, the action plans allow the NSAG a certain degree of autonomy, almost an initiation into the 'adult' world of international subjects, enabling their participation and giving them a chance to prove themselves, whilst maintaining the 'training wheels' and the ability of the Security Council to reign them in should they fail to honour the agreement. ${ }^{25}$ Despite the positive impact that the action plans can have, they are not able (nor are they intended) to have a broader impact on the enjoyment of human rights within an area controlled by a NSAG. Therefore, whilst they can contribute towards the governance of the actions of NSAGs, their specificity prohibits them from filling the governance gap in a more general manner. If one takes a regulatory governance approach (achieving effective governance through complementary measures at the local, national and international level, by a range of actors) (e.g. LeviFaur 2010, 13-14) to the issue of NSAGs, this is not of itself a negative consequence, but it does point to 
the need to take further action to relieve situations of humanitarian crisis.

B. Deeds of commitment

Similar comments can be made in relation to Geneva Call's Deeds of Commitment. There are three types of commitment, dealing with antipersonnel mines, the protection of children from the effects of armed conflict and the prohibition of sexual violence and gender discrimination (see Geneva Call 2014a, 2014b). The deed relating to the protection of children has been a landmark development within the global campaign against child soldiers. The deed is the first international instrument that NSAGs could voluntarily and unilaterally sign and be judged upon their implementation thereof. Nevertheless, they may only have real value as a positive gesture. The deeds have been instrumental in raising awareness and encouraging NSAGs to consider the human rights impacts of their actions more concretely. In particular, the deed for the prohibition of sexual violence and gender discrimination provides a substantial list of commitments to which the groups agree to adhere to. These include certain provisions that would also fall under international human rights law, such as a prohibition of discrimination against women and equal access to healthcare (Geneva Call 2013a, para 5). Additionally, the deed does acknowledge that it is "one step or part of a broader commitment" to human rights and humanitarian law (Geneva Call 2013a, para 9). Nonetheless, there is no direct reference to human rights obligations of NSAGs.

In contrast, the deed on the protection of children does mention human rights in its main provisions, but restricts commitment to respect for the rights to life, human dignity and development (Geneva Call 2013b, preamble). ${ }^{26}$ It is of course understandable that Geneva Call refrained from including a fuller range of human rights in the deed. Given the worries of legitimising NSAGs by holding them to the same international obligations as states during armed conflicts (which has also contributed to the fact that rules of non-international armed conflicts are less expansive than those of international armed conflicts) (Sivakumaran 2012, 68-77), concerns that NSAGs do not have the capacity to fulfil human rights obligations to the same extent as states (e.g. Moir 2002, 194, cited in Clapham 2006a, 502) and the aim of the deeds, the focus on humanitarian norms is not misplaced. Nevertheless, as per the approach taken by the Inter-American Court (discussed above), which would read some economic, social and cultural rights into the right to life, the deeds could be interpreted to impose obligations on NSAGs to contribute to the realisation of subsistence rights. But even if the deeds were to be read as such, two main problems ensue. On the one hand, the commitment is to 'respect' the rights, which under international human rights law is an obligation to refrain from interfering with the enjoyment of human rights. Individuals in situations of humanitarian crisis, however, require their rights to be fulfilled. This obliges obligation-holders to (i) facilitate the realisation of rights by taking "positive initiatives to enable the full enjoyment" and (ii) provide "direct or indirect state services when individuals or groups are unable, for reasons beyond their control, to realise the right themselves by the means at their disposal" (see respectively, CESCR 1999a, para 15; CESCR 1999b, para 6). This goes considerably beyond an obligation to refrain from taking action and cannot legitimately be read into a commitment to 'respect' rights. The other problem is the non-binding nature of deeds and the lack of any enforcement mechanism for them, which may not result in concrete improvement of victim's right, and the link between the deed and obligations of subsistence rights is a somewhat tenuous basis for imposing a direct obligation on NSAGs.

C. Outcomes of the initiatives

As has been indicated, the outcomes of these two initiatives have not been as positive as one would have hoped. Unfortunately, as the Security Council noted in its Fifth Cross-Cutting Report, published in 2013, "there has been little movement in getting non-state actors to agree to action plans" regarding child soldiers, compared to more successful efforts in relation to state forces (United Nations Security Council 2012). Furthermore, as of 2011, less than $15 \%$ of NSAGs using child soldiers had agreed to one of the aforementioned action plans (see Watchlist on Children in Armed Conflict 2011, 6); although in recent years, there have been some signings of the action plans and consequent de-listing of NSAGs. ${ }^{27}$ This suggests that the action plans are proving useful in the effort to regulate the actions of NSAGs. The deeds of commitment dealing with anti-personnel mines have received a significant number of signatures, whilst the other two deeds have received much fewer. ${ }^{28}$ Despite not having a mechanism comparable to the removal of groups from the list of shame, Geneva Call has been extremely active in following up on deeds of commitment. For example, they have provided training for some NSAGs on how they can put their commitments into practice (e.g. in Syria: Geneva Call, 2014b), and they continue to monitor groups 
to ensure that they are implementing the agreements (Geneva Call 2015a). This is an important step in being able to fulfil the deeds' goals of holding NSAGs publicly accountable for their actions (Geneva Call 2015b). For a NSAG, signing a deed of commitment is one step towards acknowledging (albeit limited) international responsibility for its actions. The deeds suggest that once engaged, NSAGs are willing and capable of taking commitments seriously. If groups are hoping to establish themselves as a legitimate authority, it is crucial for them to be seen to make a tangible effort to abide by international obligations to which they would be bound were they to succeed. This is all the more important in light of the Articles on the Responsibility of States for Internationally Wrongful Acts (International Law Commission 2001), according to which an insurrection group that succeeds in becoming the legitimate authority of a state may be held, ex post facto, internationally responsible for any breaches of international law that may be attributed to it before it came into power (Article 10). However, notwithstanding great expectations being placed on United Nations action to combat the use of child soldiers, reports show that the technique of naming and shaming has not been successful. Instead of decreasing the prevalence of child soldiers, the most recent report by the SecretaryGeneral on children and armed conflict states that there are currently 57 groups in 15 countries that are recruiting or using child soldiers, ${ }^{29} 17$ of which have remained on the list for 5 years or more (Coomaraswarmy 2012, Annex 1). In contrast, only five groups were 'de-listed' in the last year. ${ }^{30}$ In addition, the prohibition of the recruitment and use of child soldiers by NSAGs in Article 4 to the Optional Protocol to the CRC does not afford as effective protection as may be hoped. The lack of monitoring or enforcement mechanisms within the Protocol "inevitably will hinder" its effectiveness (Abraham 2003, 17). This is particularly true in relation to NSAGs, which unlike states are not subject to external monitoring mechanisms (e.g. the Human Rights Council's Universal Periodic Review). This strongly supports an argument that there need to be supplementary measures taken in the area of human rights; the current legal regimes, whether within human rights law or in other areas of international law and policy, are clearly not succeeding in their goals.

In the context of the current problem, the action plans and deeds may appear to be of limited value. However, in terms of moving forwards, Andrew Clapham has suggested extending the commitments to cover more detailed human rights abuses (Clapham 2006b, 292-293). On a similar vein, Solimon Santos has envisaged Geneva Call basing these commitments on human rights in the future (Santos 2002, cited in Clapham 2006b, 293). This could indeed be useful in terms of improving some NSAGs' protection of subsistence rights during humanitarian crises. A human rights-specific commitment could include a provision that NSAGs who are in an ongoing conflict (or conflicts) agree that, should a situation of humanitarian crisis arise, they will fulfil certain obligations relating to subsistence rights (i.e. the minimum core). This could go some way to rectifying the main problem of using deeds to alleviate humanitarian crises-the lengthy process involved in their adoption and implementation. This approach would not be relevant for many NIAC and would still require methods capable of providing a much more immediate response. A suggested method for this will be submitted below.

\section{Common Article 3 special agreements}

One example of such an agreement is a 'special agreement' adopted pursuant to Common Article 3 of the four Geneva Conventions. As mentioned above, unless Additional Protocol II applies, Common Article 3 is the only treaty norm applicable to NIAC. The provision encourages parties to NIAC to bring other provisions of the Geneva Conventions into force through a special agreement. The agreements may state the law that parties are already bound to follow (declaratory agreements) or extend their legal obligations (constitutive agreements). Special agreements constitute clear commitments by parties to a conflict, providing an "important basis for followup interventions to address violations of the law" (ICRC $2008,16)$. The agreements can also potentially remedy the gap between law and practice that exists in relation to NIAC, and the application of more extensive norms can ensure more equal protection of civilians during international and internal armed conflicts. Indeed, practice relating to special agreements shows that most agreements adopted involve those humanitarian norms concern the protection of civilians (Clapham et al. 2015, 513). However, the agreements have not been particularly popular in practice (Clapham et al. 2015, 511), and for the purposes of protecting subsistence rights during humanitarian crises, they are fundamentally limited by their restrictive scope of their coverage (i.e. the Geneva Conventions). Nonetheless, lessons may be learned from the agreements which have arguably been the inspiration for agreements through which NSAGs assume both humanitarian and human rights obligations, which will be discussed in the following section. 


\section{Human rights agreements}

Other than the voluntary commitments by NSAGs, there have also been examples of human rights agreements between NSAGs and states. Perhaps the most famous of these is the human rights agreement concluded between the Frente Farabundo Martí para la Liberación Naçional (FMLN) and the government of El Salvador in 1990. The Acuerdo de San José sobre Derechos Humanos 1990 included provisions that the NSAGs would comply with the same human rights obligations as the El Salvadorian state-a significant undertaking. The obligations of the FMLN in relation to particular human rights, for example the rights to freedom of association, expression and movement, are elaborated upon within the agreement. Although the more specific obligations relate more to civil and political rights as opposed to economic, social and cultural rights, the agreement was very significant for two reasons. First, in terms of disregarding concerns of states that giving NSAGs direct human rights obligations would grant the groups unwelcome legitimacy ${ }^{31}$ and second in the fact that the United Nations endorsed and agreed to monitor implementation of the agreement. ${ }^{32}$ The recognition of the agreement's preamble that the FMLN had the capacity to fulfil the human rights obligations is also worthy of note, especially given widespread opposition to horizontal effect for this reason (Zegveld 2002).

Another example of a bilateral agreement including human rights norms is the Comprehensive Agreement on Respect for Human Rights and International Humanitarian Law between the National Democratic Front of the Philippines and the Government of the Philippines 1998. The Agreement included a whole section dedicated to an impressive range of human rights. ${ }^{33}$ Although a laudable effort and very much a positive development in itself, the ensuing peace was not long-lasting. This rendered the governance potential of the agreement effectively null, with renewed efforts at reconciliation between the parties repeatedly falling through. ${ }^{34}$ In addition, the agreements would need to include specific provision for subsistence rights in order to make sure that their protection during humanitarian crises would be provided for. This may not be a problem in itself, but the low likelihood of such a human rights agreement having been adopted before a situation of humanitarian crisis caused by a NIAC is more problematic. Together with the rarity of states agreeing to acknowledge the validity of declarations and agreements of NSAGs, this suggests that a new approach is necessary.

\section{Ceasefire agreements: an alternative solution?}

Given the above shortcomings of previous initiatives, it is submitted that a new approach must be taken to increase the potential of human rights observance by NSAGs during humanitarian crises. To avoid some of the challenges faced by measures such as the deeds of commitment and more general human rights agreements (e.g. engagement with NSAGs and state recognition of agreements), this approach should use an existing measure that is already accepted by states and NSAGs, in a new way. The measure proposed is the use of ceasefire agreements between parties to a NIAC.

\section{The nature and content of ceasefire agreements}

The term 'ceasefire agreement' refers to an agreement between two parties engaged in conflict with each other to end hostilities. Ceasefire agreements may take several forms, cover different scopes of content and durability and have different purposes. For example, an agreement may aim to establish peace through a complete cessation of hostilities (also referred to as 'peace agreements'). Ceasefire agreements may also be made as a way of temporarily ceasing hostilities in order to enable the parties to a conflict to negotiate a full peace agreement. Alternatively, a ceasefire agreement may be more limited in temporal scope. Such agreements are often adopted for humanitarian purposes, to allow civilians temporary relief from hostilities in order to get access to essential materials (such as those seen between Hamas and Israel). ${ }^{35}$

The recommendations of using ceasefire agreements will focus on the latter type of agreement, rather than peace agreements (and long-term ceasefire agreements). The latter, although perhaps the most significant ceasefire agreements when successfully implemented, are of less relevance for present purposes. This is because although some such agreements have been adopted in the past (e.g. the Comprehensive Peace Accord between the Government of Nepal and the Communist Party of Nepal (Maoist) 2006), they can take many years of negotiation to come to fruition. Indeed, taking the example of the Colombian government, which has been negotiating various peace agreements with the FARC for decades, it is evident that in some situations, a long-term ceasefire agreement is extremely unlikely to be adopted. As the problem faced in this paper is to provide a relatively fast response to situations of humanitarian crisis, peace agreements would not be the most effective solution.

In addition, it is important to note at this juncture the legal status of peace agreements. Prior to 2005, peace agreements were understood as being legally binding documents, serving as a kind of contract between the signatory parties (Kastner 2015, 13). Since the Armed Activities Case before the ICJ (International Court of Justice 2005), however, the status of peace agreements has been in doubt. In this case, the Court effectively 'downgraded' the status of peace agreements from legally binding instruments to modus operandi (para 99). The reasoning for this seems to have been to prevent states from relying on peace agreements to escape international responsibility for wrongful acts (an argument 
on which Uganda was relying in the case) (Lang 2008, 109). Andrea Lang has argued that the Court's judgement was also based on a reluctance to engage with the issue of the status of NSAGs under international law (Lang 2008, 125), which is an issue that would be unavoidable, should agreements signed by NSAGs constitute a legally binding document. However, the legal status of the kinds of ceasefire agreements between states and NSAGs focused on in the current paper remains somewhat anomalous (see Kastner 2015, 13-14). Even though many of these agreements do not fall within the realm of public international law, it is still possible for a NSAG to conclude a legally binding agreement with states (for example by "including a third state party as a guarantor or using a Security Council Resolution": Public International Law and Policy Group 2013, 7). The legal status of the agreements proposed will therefore depend upon the situations of their adoption.

Ceasefire agreements generally consist of three core elements, which provide for "(1) a cessation of hostilities, (2) the separation of forces, and (3) the verification, supervision, and monitoring of the agreement" (Public International Law and Policy Group 2013, 1). A key component to the success of ceasefire agreements is to "clearly indicate the rights and obligations of the parties" (ibid, 1-2). This component is of particular relevance here, as it suggests that some level of detail concerning the rights and obligations is required. This supports (in light of the above discussion as to the relevant lex specialis) an argument that human rights norms, rather than humanitarian norms should be included in the agreement to improve the protection of subsistence rights.

\section{Ceasefire agreements as a tool for compliance}

In using ceasefire agreements as a tool for NSAGs' compliance with human rights law to improve protection of subsistence rights during humanitarian crises, it is envisaged that provisions detailing the relevant norms of human rights law and the standards expected to be upheld by parties to the conflict will be included. The advantages and disadvantages of this approach will now be examined.

\section{Advantages of using ceasefire agreements}

One advantage of using ceasefire agreements concerns the fact that their use is already widely accepted by both states and NSAGs, reflected in the prevalence of their adoption. In relation to the conflict in Myanmar alone, for example, ceasefire agreements have been adopted between the government and 14 non-state armed groups (Oo 2014, 7). In light of the reluctance of states to endorse NSAGs' unilateral declarations or agree to Common Article 3 Special Agreements (premised on a concern that to do so would "grant a degree of legitimacy" upon the group:
ICRC 2014, 17), the acceptance by both actors is extremely advantageous.

Including human rights obligations in ceasefire agreements that are already being negotiated would also be less resource-intensive and faster than the adoption of (for example) a new agreement specifically for the imposition of human rights obligations. In particular, short-term ceasefire agreements may be used to place economic, social and cultural rights obligations on NSAGs and states alike. The kinds of obligations envisaged would admittedly depend on the situation on the ground. For example, the capacity of the NSAGs to fulfil obligations and the nature of the humanitarian crisis would require careful consideration. However, ceasefire agreements often include humanitarian considerations relating to economic, social and cultural rights (for example provisions relating to the delivery of aid). ${ }^{36}$ Making the human rights aspects of these provisions explicit could be a reasonable way of placing more direct human rights obligations on NSAGs in a position to fulfil subsistence rights. This is especially true given that there are already some ceasefire agreements that include human rights-related provisions and work towards the protection of international humanitarian law and humanitarian aid (Reuters 2014). For example, the agreement between the Government of Nepal and the Communist Party of Nepal provides an expansive list of human rights obligations for both parties, ranging from the right to life and the prohibition of torture to the right to food and the right to health. As such, including more context-specific and detailed human rights obligations for NSAGs in ceasefire agreements would not be an excessive development.

Another advantage of using ceasefire agreements in this way is that it could open the door to more human rights agreements. Just as short-term ceasefire agreements often pave the way to the adoption of a peace agreement, they could form a stepping stone to more agreements like that between El Salvador and the FMLN, with a longer time span and more extensive human rights protection.

In addition, the agreements would only affect the specific NSAG subject to the agreement. On the one hand, this should mollify state concerns that more general human rights agreements for NSAGs would either grant them legitimacy or move too far towards treating them as subjects of international law. As such, the agreements would not be as invasive into the international legal framework as would a more general legally binding human rights instrument for NSAGs. On the other hand, ceasefire agreements can include conflict-specific details. This is crucial when dealing with different groups, their mode of operations and the specific challenges faced in trying to improve access to subsistence rights in a particular rebel-held area. 
A further advantage to using ceasefire agreements is the huge symbolic value that they would have. From the perspective of NSAGs, they could be a way for them to prove that they have both the willingness and capacity to act as a state-like entity within the international arena. Whether or not this is desirable from an objective perspective, the group may enhance its reputation both with the individuals over which they exercise control and the international community at large. They would, nevertheless, fall short of changing the groups' status under international law. Since NSAGs already conclude ceasefire agreements, no developments in the international legal framework would be necessary.

Furthermore, and of great importance, the agreements could result in less discriminatory protection of human rights. Although victims of more even and fair protection of human rights would not be able to receive the same redress for violations as they would against a state (i.e. bringing a complaint before a human rights treaty monitoring body or court), since many ceasefire agreements are monitored by the United Nations (which would ideally be the case here), it may be possible for them to gain some redress. The type of redress available would of course depend upon the provisions and circumstances under which the agreement is drafted and the extent to which the parties would consent to be monitored. The fact that the agreements require consent from both parties would, however, increase the legitimacy of the obligations placed on the parties. ${ }^{37}$ Concerns as to the (particularly procedural) legitimacy (Ryngaert 2010, 73) of direct human rights obligations for NSAGs could be mitigated by the inclusion of the NSAG in the drafting process and ultimately by their consent in the adoption of the ceasefire agreement. This may also make NSAGs more likely to observe the obligations to which they commit themselves. Indeed, the importance of engaging with non-state actors before requiring certain behaviour of them has been repeatedly stressed (see United Nations Secretary-General Ban Ki-moon 2011, cited in International Peace Institute 2012). The importance of engagement is reflected through the work of Geneva Call, which has "demonstrate[d] that constructive engagement with [armed non-state actors] can be effective and can yield tangible benefits for the protection of civilians" (Bongard 2013).

Finally, from the perspectives of states, the agreements may be more palatable than the adoption of a more general agreement imposing human rights obligations on NSAGs. Indeed, in adopting an agreement, they could be seen to be fulfilling their own due diligence obligations; adopting an agreement with a NSAG which would compel the group to protect human rights within the territory control could be considered a means of encouraging NSAGs to respect human rights. In this way, although the idea of acknowledging that NSAGs are capable of fulfilling some human rights obligations may not be attractive to states, doing so in a way which allows the NSAG to be held accountable may actually work in their favour.

\section{Disadvantages of using ceasefire agreements}

Whilst the inclusion of economic, social and cultural rights obligations in ceasefire agreements has many advantages, they unfortunately also have some drawbacks. Most of these relate not to the use of the agreements per se, but to issues of their adoption and enforcement.

Perhaps the greatest disadvantage is the fragile nature of ceasefire agreements. Practice shows that the rate of violation of ceasefire agreements is very high. It is therefore likely that future agreements including human rights obligations would also be breached. However, there are techniques relating to the drafting and implementation of ceasefire agreements that can mitigate these risks. It has been suggested, for example, that drafting provisions within ceasefire agreements as precisely as possible (in terms of the obligations and geographical and temporal scope) can facilitate effective implementation (Hayson and Hottinger 2004, 2). Effective implementation often relies on a monitoring mechanism for a ceasefire agreement, agreed to between all parties (Hayson and Hottinger 2004, 6). Unfortunately, such a mechanism would be less amenable for the shortterm ceasefire agreements in question. This constitutes a disadvantage of their use related to their short-term nature, which could prevent the agreements from having a long-term impact on economic, social and cultural rights realisation. Providing a long-term solution is not the intention behind the suggestion, however. Instead (and contrary to common ideas of seeing economic, social and cultural rights as long-term goals to be achieved in the future), one aim of the agreements is to place more focus on the potential of economic, social and cultural rights to contribute to solving very immediate problems.

A further disadvantage of the proposal is that although ceasefire agreements and peace agreements have been adopted between state and non-state groups in the past, ${ }^{38}$ the addition of human rights provisions in the agreements may perturb a NSAG. This will of course depend on the individual group, their aims and motivation and how important third party opinions are to them. A group that seeks to establish itself as a new state, for example, may be more willing to take on these typically state obligations. This is evident from examples such as the National Liberation Front of Algeria and the Palestine Liberation Organization (Higgins 2004, 24-26). Other groups who have an ideology less in line with the established global political system (for example those that operate outside of the legal regime and effectively 
disregard the international framework in place) may not consider such influences to be important (see Jo 2015). In these cases, other initiatives would have to be contemplated. However, it is crucial to acknowledge that the proposed idea of including some human rights provisions in ceasefire agreements is envisaged not as a panacea. Rather, it is intended to supplement and complement existing initiatives, forming one part of a multi-faceted governance solution.

The potential lack of political will of NSAGs and states alike to adopt the kind of ceasefire agreement suggested is a problem faced throughout the international human rights system. For example, the will of states to ratify human rights treaties (especially relating to economic, social and cultural rights) has been a challenge since their inception. ${ }^{39}$ In particular, moving from ratification as a form of lip service to the implementation of concrete human rights standards has been a constant challenge. However, the potential to have the agreements monitored by the United Nations, or perhaps by a different external monitoring body (perhaps even Geneva Call), ${ }^{40}$ would prove instrumental in ensuring that the obligations are followed.

\section{Conclusions}

The above discussions aimed to outline a prevalent and persistent challenge faced during non-international armed conflicts. The humanitarian crises being suffered by so many may be mitigated to some extent through the imposition of (temporary) human rights obligations on NSAGs. As well as remedying to a degree the inequality of obligations and human rights protection, human rights norms could be used to compliment and build upon humanitarian obligations of all parties to non-international armed conflicts. Current initiatives that have been taken to try to alleviate the human cost of armed conflicts, including action plans, the 'list of shame' and deeds of commitment, have had some success in governing the behaviour of NSAGs. Nonetheless, large lacunas exist. This is particularly with regard to the ability of the initiatives to tackle human rights protection. For this reason, a possible additional and complementary measure that could be taken is to include some subsistence rights obligations in short-term ceasefire agreements. This envisages giving human rights a larger role in the governance of NSAGs. Whilst not constituting a perfect solution, the agreements could prove to be a way of ameliorating situations of humanitarian crisis without requiring an unreasonable burden on the international community.

\section{Endnotes}

${ }^{1}$ As it is a non-governmental organisation, the definition of Geneva Call is not contained in a legally binding document. However, it is very influential, given the vast experience and work of the organisation in the field of non-international armed conflicts and in relation to NSAGs.

${ }^{2}$ 'Universal' in the sense that each member state of the $\mathrm{UN}$ has ratified the Geneva Conventions. See, e.g. ICRC (2015).

${ }^{3}$ This doctrine holds that since the "parent' state has accepted a given rule of IHL", the state may impose the obligations upon its nationals, including those who take up arms against the state or other nationals (Kleffner 2011, 445).

${ }^{4}$ That is, the argument that because individuals can be held responsible under international criminal law for war crimes, which consist of grave breaches of humanitarian law, they must therefore be obliged to comply with humanitarian law (see Kleffner 2011, 449-451).

${ }^{5}$ Article 1, para. 1 APII requires that (alongside the existence of an armed conflict within the territory of a high contracting party) non-state parties to a NIAC have "responsible command, exercise such control over a part of its territory as to enable them to carry out sustained and concerted military operations and to implement this Protocol."

${ }^{6}$ See the list of inter-state vs. intra-state armed conflicts on the International Institute for Strategic Studies (2014) Armed Conflict Database. https://acd.iiss.org/en/ conflicts?tags=CF582C41FE1847CF828694D51DE80C08. \%20Accessed\%2030\%20Nov\%202014. Accessed 1 Dec 2014.

${ }^{7}$ Whether or not the rules are effective is another question, which falls outside of the scope of this paper.

${ }^{8}$ For example, knowing how to translate the legal text into operational policies, or determining the correct scope and content of obligations.

${ }^{9}$ This is evidenced by the core principle of distinction, allowing only the targeting of 'military objectives', but allowing any such classified individual to be killed at any time during the conflict, even when not directly participating. See Article 13(1) Additional Protocol II; Solis 2010, 251-257.

${ }^{10}$ Whether the killing on sight of an enemy soldier would be classified as an 'arbitrary' execution falls outside the scope of this paper.

${ }^{11}$ For example, Common Article 3 to the four Geneva Conventions provides for an absolute prohibition of torture, of which non-observance is considered a grave breach of international humanitarian law. See, e.g. Article 130 Geneva Convention III Relative to the Treatment of Prisoners of War.

${ }^{12}$ This is pursuant to the customary humanitarian rule that prohibits "attacking, destroying, removing or rendering useless objects indispensable to the survival of the civilian population" (see ICRC 2015a, Rule 54).

${ }^{13}$ The obligation to fulfil forms part of the tripartite typology of obligations to respect, protect and fulfil 
human rights, deriving from constructions by Henry Shue and Asbjørn Eide as a way of giving content to economic, social and cultural rights (see Shue 1980; Eide 1987, cited in de Schutter 2010, 242).

${ }^{14}$ Müller applies the criteria for limitations and derogations to economic, social and cultural rights to be found legitimate to situations of armed conflict, and finds them to be met in very restricted circumstances (see Müller 2009, 557-601).

${ }^{15}$ The concept of a minimum core of human rights was introduced by the Committee on Economic, Social and Cultural Rights (CESCR), and stipulate a minimum standard, or 'floor' of fulfilment of rights which no state party may fall below, regardless of the allowance in Article 2(1) of 'progressive realisation' of the rights enshrined in ICESCR. The Committee has also emphasised that the minimum core constitutes an immediately realisable obligation for state parties, which, once established, may not be retrogressed from (see CESCR 1990, para 10).

${ }^{16}$ Article 2(1) requires states to "take steps... to the maximum of its available resources, with a view to achieving progressively the full realization of the rights recognized in the present Covenant by all appropriate means".

${ }^{17}$ The Committee stated that any retrogressive measures would "require the most careful consideration and would need to be fully justified by reference to the totality of the rights provided for in the Covenant and in the context of the full use of the maximum available resources" (CESCR, 1990: para 9).

${ }^{18}$ This would allow an individual to "enforce his fundamental rights against another individual" (Van Dijk and Van Hoof 1998, 23).

${ }^{19}$ Although the Covenants were adopted at the same time, unlike the ICCPR, the ICESCR was not accompanied by an Optional Protocol providing the Committee on Economic, Social and Cultural Rights with a mandate and jurisdiction to hear individual complaints against states for alleged violations of human rights obligations. Despite this fact, there have been some possibilities of bringing complaints directly in relation to economic, social and cultural rights prior to the Optional Protocol to ICESCR, e.g. under the Additional Protocol to the European Social Charter Providing for a System of Collective Complaints 1995, the African Charter on Human and Peoples' Rights 1981 Organization of African Unity 1981) and the Protocol to the African Charter on Human and People's Rights on the Establishment of an African Court on Human and People's Rights 1998 (Organization of African Unity 1998).

${ }^{20}$ The Protocol entered into force on 5 May 2013 (United Nations Treaty Collection Database 2015).

${ }^{21}$ The ICRC has identified the main customary international law rule as requiring parties to a conflict to "... allow and facilitate rapid and unimpeded passage of humanitarian relief for civilians in need, which is impartial in character and conducted without any adverse distinction, subject to their right of control." Basic norms regarding access to and protection foodstuffs, healthcare and humanitarian personnel in relation to NIAC can be found in Article 3(2) Geneva Conventions; Articles 9, 11 and 18 Additional Protocol II. A full explanation of the norms in NIAC can be found at ICRC (2015b). Customary IHL, Rule 55. https://www.icrc.org/customary-ihl/ eng/docs/v1_rul_rule55. Accessed 24.September 2015.

${ }^{22}$ According to Lauterpacht, this is a fundamental principle of international humanitarian law (Lauterpacht 1953, 206. Cited in Sivakumaran 2012, 242).

${ }^{23}$ The principle of individual criminal responsibility, bringing individuals within the jurisdiction of the ICC, can be found in Article 25 Rome Statute of the International Criminal Court 1998.

${ }^{24}$ The provision of other services by the FARC, such as housing, appears to be limited to its members. Indeed, the promise of a better standard of living is often cited as an incentive for joining the FARC (e.g. Council on Hemispheric Affairs 2010).

${ }^{25}$ The fact that the groups voluntarily choose and undertake the commitments in the action plans allows them to assume responsibility for their actions at an international level. This brings them one (small) step closer to experiencing the international law-making and responsibility of states.

${ }^{26}$ The fact that these commitments are only mentioned in the preamble, rather than the substantive provisions, reduces their potential influence.

${ }^{27} \mathrm{So}$ far seventeen groups have signed the action plans (twelve of which were NSAGs) with only five having been de-listed (see Office of the Special Representative of the Secretary-General for Children and Armed Conflict 2015).

${ }^{28}$ For a list of which groups have signed which deeds, see Geneva Call (2015a) Action plans with armed forces and armed groups. http://www.genevacall.org/how-we-work/ armed-non-state-actors/. Accessed 28 November 2014.

${ }^{29}$ The lists have been extended to include groups who show "patterns of killing or maiming children", "patterns of committing sexual violence against children" (both mandated by UN Security Council Resolution 1882 (2009), cited in Office of the Special Representative of the Secretary General for Children and Armed Conflict 2015) and "recurrent attacks or threats of attacks on schools and hospitals, as well as on protected persons in relation to schools and hospitals" (UN Security Council Resolution 1998 (2011), cited in Office of the Special Representative of the Secretary General for Children and Armed Conflict 2015).

${ }^{30}$ 'De-listing' refers to the removal of a party's name from the 'list of shame' pursuant to entering into one of 
the aforementioned action plans together with the Security Council (see Office of the Special Representative of the Secretary General for Children and Armed Conflict 2015).

${ }^{31}$ Through consenting to the agreement and acknowledging the fact that the FLMN has the capacity to fulfil the obligations (see Zegveld 2002, 51). This concern is often at the forefront of states' minds in the context of direct horizontal effect (see Roberts and Sivakumaran 2012, 108).

${ }^{32} \mathrm{~A}$ UN peacekeeping operation (ONUSAL) was established to monitor the agreement's implementation. Information on ONUSAL is available via the United Nations' Peacekeeping website. http://www.un.org/en/peacekeeping/ missions/past/onusalbackgr2.html. Accessed 1 December 2014.

${ }^{33}$ Part III of the agreement deals with 'Respect for Human Rights', including a list of 25 human rights to be included.

${ }^{34}$ For a summarised timeline of the conflict between the Government of the Philippines and (amongst other NSAGs) the National Democratic Front of the Philippines, see Project Ploughshares 2015).

${ }^{35}$ Noting in particular a 72-hour ceasefire agreement adopted between the parties with the aid of Egypt, in August 2014 (see Burke and Kingsley 2014).

${ }^{36}$ For example, a local ceasefire agreement adopted in Damascus (Reuters 2014).

${ }^{37}$ The argument here is that "international norms that affect non-state actors [...] are in need of the latter's participation in order to be legitimate" (Ryngaert 2010, 73).

${ }^{38}$ In Burma, for example, a group of 'ceasefire groups' emerged after the signing of several agreements between state and NSAGs (see Human Rights Watch 2007, 95).

${ }^{39}$ In relation to economic, social and cultural rights, this is evident in the fact that despite its adoption in 1966, the Optional Protocol to the International Covenant on Economic, Social and Cultural Rights did not enter into force until 2013 (UN Treaty Collection Database 2015).

${ }^{40}$ Geneva Call's experience in engaging with NSAGs and monitoring the implementation of deeds of commitment could prove invaluable in both the drafting and supervision of the ceasefire agreements suggested.

\begin{abstract}
Abbreviations
ECtHR: European Court of Human Rights; FARC: Fuerzas Armadas Revolucionarias de Colombia; FMLN: Frente Farabundo Martí para la Liberación Naçional; ICCPR: International Covenant on Civil and Political Rights; ICESCR: International Covenant on Economic Social and Cultural Rights; ICJ: International Court of Justice; ICRC: International Committee of the Red Cross; NSAG: non-state armed group.
\end{abstract}

\section{Competing interests}

The author declares that she has no competing interests.

Received: 6 October 2015 Accepted: 6 January 2016

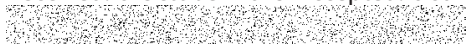

\section{References}

Abraham S (2003) Child soldiers and the capacity of the optional protocol to protect children in conflict. Human Rights Brief 10(No. 3):15-19
Acuerdo de San José sobre Derechos Humanos 1990. A/44/971-S/21541, S/21541. A translated version is available on the website of the United States Institute of Peace, Peace Agreements Digital Collection. http://www.usip.org/category/ publications/peace-agreements. Accessed 21 Jan 2016.

Australian National Security Database on Terrorist Organisations (2014). http:// www.nationalsecurity.gov.au/Listedterroristorganisations/Pages/IslamicState. aspx. Accessed 24 September 2015.

Barnes-Dacey J (2014) The Islamic State and the struggle for control in Syria. In: European Council on Foreign Relations, 2 October 2014. http://www.ecfr.eu/ article/commentary_the_islamic_state_and_the_struggle_for_control_in_ syria325. Accessed 20 Jan 2016.

Bellal A, Giacca G, Casey-Maslen S (2011) International law and armed non-state actors in Afghanistan. Int Rev Red Cross 93(881):47-79

Best G (1994) Law and War Since 1945. Clarendon Press, Oxford.

Bongard P (2013) Engaging armed non-state actors on humanitarian norms: reflections on Geneva Call's experience. In: Humanitarian Exchange Mission, p 58. http://odihpn.org/magazine/engaging-armed-non-state-actors-onhumanitarian-norms-reflections-on-geneva-call\%C2\%92s-experience/. Accessed 20 Jan 2016.

Burke J, Kingsley P (2014) Israel and Hamas agree Egyptian proposal for 72-hour Gaza ceasefire., The Guardian, http://www.theguardian.com/world/2014/aug/ 10/gaza-israel-hamas-agree-72-hour-ceasefire-egyptian-proposal. Accessed 5 December 2014

CESCR (1990) General comment no. 3: the nature of state parties' obligations (art. 2, para. 1, of the Covenant)., p E/1991/23

CESCR (1999a) General comment no. 12: substantive issues arising in the implementation of the international covenant on economic, social and cultural rights: the right to adequate food (art.11)., p E/C.12/1999/5

CESCR (1999b) General comment no. 13: the right to education (art.13)., p E/C.12. 1999/10

Clapham A (2006a) Human rights obligations of non-state actors in conflict situations. Int Rev Red Cross 88(863):491-523

Clapham A (2006b) Human rights obligations of non-state actors. Oxford University Press, Oxford

Clapham A, Gaeta P (2014) The Oxford handbook of international law in armed conflict. Oxford University Press, Oxford

Clapham A, Gaeta P, Sassòli M (2015) The 1949 Geneva Conventions: a commentary. Oxford University Press, Oxford

Cleveland S (2014) Harmonizing standards in armed conflict EJILTalk! http://www. ejiltalk.org/harmonizing-standards-in-armed-conflict/. Accessed 24 September 2015.

Columbia Law School Human Rights Institute. Harmonizing standards in armed conflict. http://web.law.columbia.edu/human-rights-institute/ counterterrorism/harmonizing-standards-armed-conflict. Accessed 20 Jan 2016.

Comprehensive Agreement on Respect for Human Rights and International Humanitarian Law between the Government of the Republic of the Philippines and the National Democratic Front of the Philippines 1998. http:// www.incore.ulst.ac.uk/services/cds/agreements/pdf/phil8.pdf. Accessed 5 December 2014.

Comprehensive Peace Accord between the Government of Nepal and the Communist Party of Nepal (Maoist) 2006 (translation). United States Institute of Peace. http://www.usip.org/publications/peace-agreements-nepal. Accessed 20 Jan 2016.

Coomaraswarmy R (2012) United Nations General Assembly Annual report of the Special Representative of the Secretary-General for Children and Armed Conflict. A/HRC/21/38, Radhika Coomaraswamy

Council of Europe, Additional Protocol to the European Social Charter Providing for a System of Collective Complaints 1995. Strasbourg, European Treaty Series, No. 158, 9.XI.1995

Council on Hemispheric Affairs (2010) FARC - rebels with a cause? http://www. coha.org/farc---rebels-with-a-cause/. Accessed 25 September 2015.

de Schutter O (2010) International human rights law: cases, materials, commentary. Cambridge University Press, Cambridge

Eide A (1987) Report on the right to adequate food as a human right., E/CN.4/ Sub.2/1987/23

European Court of Human Rights (1998a) Kaya v Turkey., Application No. 22729/93

European Court of Human Rights (2005) Case of Fadeyeva v. Russia., Application No. $55723 / 00$

European Court of Human Rights (1999) Case of Illascu and others v. Moldova and Russia., Application no. 48787/99 
European Court of Human Rights (1998b) Osman v. United Kingdom., Application No. $87 / 1997 / 871 / 1083$

European Court of Human Rights (1985) X and Y V. The Netherlands., Application No. $8978 / 80$

European Court of Human Rights (2001) Z and Others v. United Kingdom., Application No. 29392/95

Geneva Call Deed of Commitment. http://www.genevacall.org/how-we-work/ deed-of-commitment/. Accessed 30 November 2014.

Geneva Call (2013a) Deed of commitment under Geneva Call for the prohibition of sexual violence in situations of armed conflict and towards the elimination of gender discrimination. http://www.genevacall.org/wp-content/ uploads/dlm_uploads/2013/12/DoC-Prohibiting-sexual-violence-and-genderdiscrimination.pdf. Accessed 20 Jan 2016.

Geneva Call (2013b) Deed of Commitment under Geneva Call for the protection of children from the effects of armed conflict. http://www.genevacall.org/ wp-content/uploads/dlm_uploads/2013/12/DoC-Protecting-children-inarmed-conflict.pdf. Accessed 20 Jan 2016.

Geneva Call (2014a) Deed of Commitment. http://www.genevacall.org/how-wework/deed-of-commitment/. Accessed 28 November 2014

Geneva Call (2014b) Syria: Geneva Call trained Kurdish authorities and police forces on international humanitarian norms. http://www.genevacall.org/syriageneva-call-trained-kurdish-authorities-police-forces-internationalhumanitarian-norms/. Accessed 28 November 2014.

Geneva Call (2015a) Action plans with armed forces and armed groups. http:// www.genevacall.org/how-we-work/armed-non-state-actors/. Accessed 28 November 2014

Geneva Call (2015b) Somalia. http://www.genevacall.org/country-page/somalia/. Accessed 28 November 2014.

Harvey R (2003) Children and armed conflict: a guide to international humanitarian and human rights law. Int Bureau Human Rights: 29-30. http://www.ibcr.org/editor/assets/Conflict_Eng.pdf. Accessed 19 Jan 2016.

Hayson N, Hottinger J (2004) 'Do's and dont's of sustainable ceasefire agreements, Peace Appeal Foundation 2. http://peacemaker.un.org/sites/ peacemaker.un.org/files/DosAndDontofCeasefireAgreements HaysomHottinger2010.pdf. Accessed 21 Jan 2016.

Higgins N (2004) The application of international humanitarian law to wars of national liberation., J Humanitarian Assistance, http://sites.tufts.edu/jha/files/ 2011/04/a132.pdf. Accessed 20 Jan 2016

Hubbard B (2014) ISIS tightens its grip with seizure of air base in Syria. In: The New York Times, 24 August 2014. http://www.nytimes.com/2014/08/25/ world/middleeast/isis-militants-capture-air-base-from-syrian-governmentforces.html. Accessed 5 December 2014.

Human Rights Council, Working Group on the Universal Periodic Review (2008) National report submitted in accordance with paragraph 15(a) of the annex to human rights council resolution 5/1. A/HRC/WG.6/3/COL/1, Colombia

Human Rights Watch (2007) Sold to be soldiers: the recruitment and use of child soldiers in Burma. Human Rights Watch 19(15):C

ICRC (2004) What is International Humanitarian Law? https://www.icrc.org/eng/ assets/files/other/what is ihl.pdf. Accessed 20 Jan 2016.

ICRC (2008) Increasing respect for international humanitarian law on noninternational armed conflicts https://www.icrc.org/eng/assets/files/other/icrc 002_0923.pdf. Accessed 14 August 2015.

ICRC (2014) Q\&A and lexicon on humanitarian access. Retrieved 28 September 2015. http://www.icrc.org/eng/assets/files/2014/icrc-q-and-a-lexison-onhumanitarian-access-06-2014.pdf.

ICRC (2015a) Customary IHL, rule 54. https://www.icrc.org/customary-ihl/eng/ docs/v1_rul_rule54. Accessed 24 September 2015

ICRC (2015b) Customary IHL, rule 55. https://www.icrc.org/customary-ihl/eng/ docs/v1_rul_rule55. Accessed 24 September 2015

ICRC (1949a) Geneva Convention for the Amelioration of the Condition of the Wounded and Sick in Armed Forces in the Field (First Geneva Convention)., 75 UNTS 31

ICRC (1949b) Geneva Convention for the Amelioration of the Condition of Wounded, Sick and Shipwrecked Members of Armed Forces at Sea (Second Geneva Convention)., 75 UNTS 85

ICRC (1949c) Geneva Convention Relative to the Treatment of Prisoners of War (Third Geneva Convention)., 75 UNTS 135

ICRC (1977) Protocol additional to the Geneva Conventions of 12 August 1949, and relating to the protection of victims of non-international armed conflicts (protocol II)., 1125 UNTS 609 (AP II)

ICRC (1949d) Geneva Convention Relative to the Protection of Civilian Persons in Time of War (Fourth Geneva Convention)., 75 UNTS 287
Inter-American Commission on Human Rights, Organization of American States (1999) Third report on the human rights situation in Colombia., OEA/Ser.LN/ll.102

Inter-American Court of Human Rights (2004) Case of Children's Rehabilitation v. Paraguay. Inter-Am Ct HR (Ser. C) No. 112

Inter-American Court of Human Rights (1988) Velásquez-Rodríguez v. Honduras., (Ser.C) No.4

Inter-American Court of Human Rights (2006) Yakye Axa Indigenous Community v. Paraguay. Interpretation of the Judgment on Merits and Reparation Ser. C:142

International Court of Justice (2005) Case concerning armed activities on the territory of the Congo (Democratic Republic of the Congo v. Uganda)., p 168, I.C.J. Reports

International Court of Justice (2004) Legal consequences of the construction of a wall in the occupied Palestinian territory, advisory opinion

International Law Commission (2001) Draft articles on responsibility of states for internationally wrongful acts. Supplement 10(A/56/10):chp.IV.E.1

International Peace Institute (2012) Engaging nonstate armed groups on the protection of children: towards strategic complementarity: 1. http:// www.genevacall.org/wp-content/uploads/dlm_uploads/2013/12/EngagingNonstate-Armed-Groups-on-the-Protection-of-Children-Towards-StrategicComplementarity-International-Peace-Institute..pdf. Accessed 20 Jan 2016

International Institute for Strategic Studies (2014), Armed Conflict Database. https://acd.iiss.org/en/conflicts?tags=CF582C41FE1847CF828694D51DE80C08. \%20Accessed\%2030\%20Nov\%202014. Accessed 1 Dec 2014.

International Institute of Humanitarian Law (2006) The Manual on the Law of NonInternational Armed Conflict With Commentary. http://www.iihl.org/wp-content/ uploads/2015/12/Manual-on-the-Law-of-NIAC.pdf. Accessed 19 Jan 2016.

Jo H (2015) Compliant rebels: rebel groups and international law in world politics. Cambridge University Press, Cambridge

Kastner P (2015) Legal normativity in the resolution of internal armed conflicts. Cambridge University Press, Cambridge

Kleffner JK (2011) The applicability of international humanitarian law to organized armed groups. Int Rev of the Red Cross 93(882):443-461

Kreiger H (2006) A conflict of norms: the relationship between humanitarian law and human rights law in the ICRC Customary Law Study. J Conflict and Sec L 11:271

Lang A (2008) Peace agreements in international conflict resolution. Int $L$ and Politics 40:107

Lauterpacht H (1953) The Limits of the Operation of the Law of War. British Yearbook Int. L 30

Leech G (2013) FARC rebel groups in peace talks: is Colombia's 50-year war about to end? In: The Independent. http://www.independent.co.uk/news/ world/americas/farc-rebel-group-in-peace-talks-is-colombias-50year-warabout-to-end-8722917.html. Accessed 28 November 2014

Levi-Faur D (2010) Regulation and Regulatory Governance. Jerusalem Papers in Regulation and Governance Working Papers Series Working Paper No. 1

Melish TJ (2008) The inter-American court of human rights. In: Langford M (ed) Social rights jurisprudence emerging trends in international and comparative law. Cambridge University Press, Cambridge, pp 372-408

Milanović M (2011) Norm conflicts, IHL and IHRL. In: Ben-Naftali O (ed) International Humanitarian Law and International Human Rights Law. Oxford University Press, Oxford, pp 95-125

Moir L (2002) The law of internal armed conflict. Cambridge University Press, Cambridge

Moir L (1998) The Historical Development of the Application of Humanitarian Law in Non-International Armed Conflict in 1949. International Comparative Law Quarterly 47(2):337-361

Müller A (2009) Limitations to and derogations from economic, social and cultural rights. Human Rights L Rev 9:557-601

Office for the United Nations High Commissioner for Human Rights (2005) Economic, social and cultural rights: handbook for national human rights institutions, professional training series no. 12: 61. http://www.ohchr.org/ Documents/Publications/training12en.pdf. Accessed 2 December 2014

Office of the Special Representative of the Secretary General for Children and Armed Conflict (2009) Role of the Security Council. http://www. childrenandarmedconflict.un.org/our-work/engagement-of-the-securitycouncil/. Accessed 1 December 2014

Office of the Special Representative of the Secretary General for Children and Armed Conflict (2015) Listing parties to conflict who commit grave violations against children. https://childrenandarmedconflict.un.org/our-work/sg-list/. Accessed 30 November 2014. 
Office of the Special Representative of the Secretary-General for Children and Armed Conflict (2009) Working paper no. 1-the six grave violations against children during armed conflict: the legal foundation

Office of the Special Representative of the Secretary-General for Children and Armed Conflict (2015) Action plans with armed forces and armed groups. http://childrenandarmedconflict.un.org/our-work/action-plans/. Accessed 6 August 2013

Oo MZ (2014) Understanding Myanmar's peace process: ceasefire agreements, Swiss Peace, http://www.swisspeace.ch/fileadmin/user_upload/Media/ Publications/Catalyzing_Reflections_2_2014_online.pdf. Accessed 20 Jan 2016

Organization of African Unity (1981) African Charter on Human and Peoples' Rights ("Banjul Charter")., CAB/LEG/67/3 rev 5, 21 ILM 58

Organization of African Unity (1998) Protocol to the African Charter on Human and People's Rights on the Establishment of an African Court on Human and People's Rights

Peralta E (2014) U.N.: Syrian refugee crisis is 'biggest humanitarian emergency of our era". NPR. http://www.npr.org/blogs/thetwo-way/2014/08/29/344219323/ u-n-syrian-refugee-crisis-is-biggest-humanitarian-emergency-of-our-era. Accessed 25 September 2015

Project Ploughshares (2015) Philippines-CPP/NPA (1969_first combat deaths). http://ploughshares.ca/pl_armedconflict/philippines-cppnpa-1969-firstcombat-deaths/. Accessed 25 September 2015

Reuters (2014) Truce in Damascus district allows in aid: monitor. http://www. reuters.com/article/us-syria-crisis-damascus-idUSKCNOIWOQP20141112. Accessed 20 Jan 2016

Roberts A, Sivakumaran S (2012) Lawmaking by nonstate actors: engaging armed groups in the creation of international humanitarian law. 37(1). The Yale Jof Int Law 37(1):107-152

Rollins J (2010) International terrorism and transnational crime: security threats, U. S. policy, and considerations for congress. Congressional Research Service Report for Congress

Rosas A, Sandvik-Nylund M (2001) Armed conflicts. In: Eide A, Krause C, Rosas A (eds) Economic, Social and Cultural Rights: A Textbook. Martinus Nijhoff Publisher, Dordrecht

Rottensteiner C (1999) The denial of humanitarian assistance as a crime under international law. Int Rev Red Cross No. 835. https://www.icrc.org/eng/ resources/documents/misc/57jq32.htm. Accessed 20 Jan 2016.

Ryngaert C (2010) Imposing international duties on non-state actors and the legitimacy of international law. In: Noortmann M, Ryngaert C (eds) Non-state actor dynamics in international law: from law taking to law making? Ashgate Publishing Group, Surrey

Ryngaert C, Van de Meulebroucke A (2012) Enhancing and enforcing compliance with international humanitarian law by non-state armed groups: an enquiry into some mechanisms. J Conflict Sec Law 16(3):443-472

Santos SM (2002) Geneva Call's Deed of Commitment for armed groups: an annotation. In: Geneva Call (2002) Seeking Rebel Accountability: Report of the Geneva Call Mission to the MILF in the Philippines

Schabas W (2007) Lex Specialis? Belt and suspenders? The parallel operation of human rights law and the law of armed conflict, and the conundrum of Jus ad Bellum. Israel L Rev 40(2):592-594

Secretary General on children and armed conflict (2002) Third report of the Secretary General on children and armed conflict. S/2002/1299

Shue H (1980) Basic rights, subsistence, affluence and U.S. foreign policy. Princeton University Press, Princeton

Sivakumaran S (2012) The law of non-international armed conflict. Oxford University Press, Oxford

Solis GD (2010) The law of armed conflict: international humanitarian law in war. Cambridge University Press, Cambridge

Swiss Federal Department of Foreign Affairs (2011) Humanitarian access in situations of armed conflict: handbook on the normative framework version 1.0. http://cdint.org/documents/CDI_Access_Manual_Web_Dec5.pdf. Accessed 20 Jan 2016

United Nations Commission on Human Rights (1987) Note verbale dated 89/12/ 05 from the Permanent Mission of the Netherlands to the United Nations at Geneva addressed to the Centre for Human Rights ("Limburg Principles"). E/CN.4/1987/17

United Nations Committee against Torture (1999) Sadiq Shek Elmi v. Australia., CAT/C/22/D/120/1998

United Nations General Assembly (1966a) International Covenant on Civil and Political Rights, 16 December 1966, United Nations. Treaty Series 999:171
United Nations General Assembly (1966b) International Covenant on Economic, Socia and Cultural Rights, 16 December 1966, United Nations. Treaty Series 993:3

United Nations General Assembly (2000) Optional Protocol to the Convention on the Rights of the Child on the Involvement of Children in Armed Conflict

United Nations General Assembly (1966c) Optional Protocol to the International Covenant on Civil and Political Rights, United Nations Treaty Series 999., p 171

United Nations General Assembly (1998) Rome Statute of the International Criminal Court (last amended 2010)., p 17

United Nations Human Rights Committee (2001) General Comment no. 29: states of emergency (article 4). UN Doc. CCPR/C/21/Rev.1/Add.11

United Nations Secretary-General Ban Ki-moon (2011) Remarks to the UN Security Council on November 9, 2011, during the open debate on protection of civilians. UN Doc. SG/SM/13932

United Nations Security Council (2001) Resolution 1379. S/RES/1379

United Nations Security Council (2003) Resolution 1460, S/RES/1460

United Nations Security Council (2009) Resolution 1882, S/RES/1882

United Nations Security Council (2011) Resolution 1998, S/RES/1998

United Nations Security Council (2012) Security Council report, cross cutting report: children and armed conflict no. 3. http://www.securitycouncilreport. org/atf/cf/\%7B65BFCF9B-6D27-4E9C-8CD3-CF6E4FF96FF9\%7D/cross_cutting_ report_cac_2012.pdf. Accessed November 202014

United Nations Treaty Collection Database (2015). https://reaties.un.org/Pages/ ViewDetails.aspx?src=TREATY\&mtdsg_no=IV-3-a\&chapter=4\&lang=en Accessed 20 Jan 2016

United Nations, United Nations Peacekeeping website. http://www.un.org/en/ peacekeeping/missions/past/onusalbackgr2.html. Accessed 1 December 2014

Van Dijk P, Van Hoof GJH (1998) Theory and practice of the European Convention on human rights, 3rd edn. Kluwer Law International, The Hague

Watchlist on Children in Armed Conflict (2011) Next steps to protect children in armed conflict: briefing note to the UN Security Council. In: International Peace Institute (2012) Engaging Nonstate Armed Groups on the Protection of Children: Towards Strategic Complementarity. Issue Brief. http://www. ipinst.org/publication/policy-papers/detail/355-engaging-nonstate-armedgroups-on-the-protection-of-children-towards-strategic-complementarity. html. Accessed 30 November 2014

Zegveld L (2002) Accountability of armed opposition groups in international law. Cambridge University Press, Cambridge

Zelin A (2014) The Islamic State of Iraq and Syria has a consumer protection office. http://www.theatlantic.com/international/archive/2014/06/the-isisguide-to-building-an-islamic-state/372769/. Accessed 5 December 2014.

\section{Submit your manuscript to a SpringerOpen ${ }^{\odot}$ journal and benefit from:}

- Convenient online submission

- Rigorous peer review

- Immediate publication on acceptance

- Open access: articles freely available online

- High visibility within the field

- Retaining the copyright to your article

Submit your next manuscript at $>$ springeropen.com 